\title{
Cell Therapy and Bioengineering in Experimental Liver Regenerative Medicine: In Vivo Injury Models and Grafting Strategies
}

\author{
G. Amato ${ }^{1} \cdot$ T. Saleh ${ }^{2} \cdot$ G. Carpino ${ }^{3} \cdot$ E. Gaudio $^{4} \cdot$ D. Alvaro ${ }^{1} \cdot$ V. Cardinale $^{5}$
}

Accepted: 16 March 2021 / Published online: 22 May 2021

(C) The Author(s) 2021

\begin{abstract}
Purpose of Review To describe experimental liver injury models used in regenerative medicine, cell therapy strategies to repopulate damaged livers and the efficacy of liver bioengineering.

Recent Findings Several animal models have been developed to study different liver conditions. Multiple strategies and modified protocols of cell delivery have been also reported. Furthermore, using bioengineered liver scaffolds has shown promising results that could help in generating a highly functional cell delivery system and/or a whole transplantable liver.

Summary To optimize the most effective strategies for liver cell therapy, further studies are required to compare among the performed strategies in the literature and/or innovate a novel modifying technique to overcome the potential limitations. Coating of cells with polymers, decellularized scaffolds, or microbeads could be the most appropriate solution to improve cellular efficacy. Besides, overcoming the problems of liver bioengineering may offer a radical treatment for end-stage liver diseases.
\end{abstract}

Keywords Cell therapy $\cdot$ Regenerative medicine $\cdot$ Liver damage $\cdot$ Bioengineering

\section{Experimental Liver Injury Models Used in Regenerative Medicine}

Different cell therapies and bioartificial livers have been attempted and used not only for advanced cirrhosis but also for acute and acute-on-chronic liver failure, inborn errors of metabolism, chronic cholestatic and autoimmune diseases, and non-alcoholic fatty liver disease (NAFLD) $[1 \bullet, 2,3]$.

G. Amato and T. Saleh are co-first authors.

This article is part of the Topical Collection on Cellular Transplants

V. Cardinale

vincenzo.cardinale@uniroma1.it

1 Department of Translational and Precision Medicine, Sapienza University of Rome, Rome, Italy

2 Department of Surgery, Anesthesia, and Radiology, College of Veterinary Medicine, Assiut University, Assiut, Egypt

3 Department of Movement, Human, and Health Sciences, Division of Health Sciences, University of Rome "Foro Italico", Rome, Italy

4 Department of Anatomical, Histological, Forensic Medicine, and Orthopedic Sciences, Sapienza University of Rome, Rome, Italy

5 Department of Medico-Surgical Sciences and Biotechnologies, Sapienza University of Rome, Rome, Italy
Hepatocyte transplantation represents the proof of concept of liver cell therapy [4]. Sources of liver regenerative medicine that have already been applied in the clinical setting include human hepatic stem cells (hHpSCs), human biliary tree stem cells (hBTSCs), mesenchymal stem cells (MSCs), and macrophages. A recent multicenter phase-II open-label controlled trial of hematopoietic stem cells that administered repeat autologous infusions of G-CSF-mobilized CD133+ cells to patients with advanced cirrhosis (versus conservative management or treatment with G-CSF alone) found no impact on liver function or fibrosis [5]. Tissues are highly informative, especially when clinical results are weak or absent [6]. In fact, studies have shown that the role of mesenchymal-derived cells does not depend on repopulation, but on the production of factors and cytokines with multiple effects [7, 8].

Clinical studies on liver regenerative medicine highlight the importance of solid preclinical evidence in this field. Moreover, preclinical studies should be tailored to address the questions raised by the clinical trials; e.g., the assessment of factors originating from outside the liver, such as from the gut (e.g., intestinal permeability, dysbiosis), sarcopenic muscles, or inflamed adipose tissue [6]. Importantly, liver repopulation and the proliferation and differentiation of transplanted cells should be investigated systematically in tissue over different long-term timepoints. Different experimental models 
should be evaluated to investigate specific etiopathogenetic features that may influence cell therapy outcomes. For example, models of liver fibrosis are the best candidates to study intrahepatic factors associated with the interactions and effects of exogenous cell transplantation, while NAFLD/ nonalcoholic steatohepatitis (NASH) models may reveal potential systemic factors that influence the effects of exogenous cells transplanted into the liver [6]. In the future, the in-depth study of stem/progenitor cell therapy effects could reveal antiinflammatory, antioxidant, and immunomodulatory effects that are now only studied in macrophages [8].

This review aims to provide an informative and helpful tool for designing preclinical investigations into liver regenerative medicine, including cell therapy and liver bioengineering. Although this is not a systematic review, experimental liver injury models already used in the setting of experimental liver cell therapy and other suitable models tested in rodents have been analyzed and reported, so key features can easily be appreciated, e.g., injury modality, time from injury to rescue treatment, serum tests, and histologic features (Table 1).

\section{Acute Liver Failure models}

Acute liver failure (ALF) is a condition that can arise from a broad spectrum of causes. It is characterized by the loss of hepatic, metabolic, and immunological functions $[9,10]$.

The administration of acetaminophen (APAP) to mice is the most common ALF model since the APAP doses that cause toxicity are similar in mice and humans $(\geq 150 \mathrm{mg} / \mathrm{kg})$ [11-13]. Liu et al. recently reported a study in which BALB/c mice treated with APAP were used as a model. They observed an effect of intravenously administered human umbilical cordderived mesenchymal stromal cells (hUCMSCs) through their ability to reduce hepatic necrosis/apoptosis and enhance liver regeneration [14].

A useful tool to study $\mathrm{TNF} \alpha$-mediated apoptotic signaling mechanisms $[15,16]$ and inflammatory-mediated liver injury $[15,17]$ is the D-galactosamine/endotoxin $(\mathrm{Gal} / \mathrm{ET})$ model. DGalactosamine inhibits protein synthesis by depleting uridine triphosphate pools, causing early generation of reactive oxygen species and finally apoptosis $[18,19]$, while lipopolysaccharides increase the release of proinflammatory cytokines $(\mathrm{TNF} \alpha)[20]$. Zhang et al. used this common ALF model by injecting lipopolysaccharides and D-GalN aminoglycan into mice [21] and observed a therapeutic effect of TNF $\alpha$ pretreated umbilical cord mesenchymal stem cellderived exosomes (T-Exo). They demonstrated that TExo ameliorates conditions of ALF by inhibiting the activation of the NOD-like receptor protein 3 (NLRP3)-related inflammatory pathway [22].

A relevant limitation in MSC transplantation therapy is its poor efficacy in liver colonization and viability [23]. In this context, Ma et al. used a carbon tetrachloride $\left(\mathrm{CCl}_{4}\right)$ ALF model in nude mice to study the effect of genetically modified MSCs expressing CXC receptor 4 (CXCR4). Their work showed greater colonization of the failing liver by CXCR4-MSCs, leading to reduced mortality and improved liver regeneration [24].

\section{Chronic Liver Disease Models}

Chronic liver injury is associated with fibrosis leading to cirrhosis, a disease characterized by high levels of proinflammatory cytokines $[25,26]$, an abnormal lobular architecture, and the formation of intrahepatic vascular shunts [27]. It has been demonstrated that carbon tetrachloride $\left(\mathrm{CCl}_{4}\right)$ given at low doses $(0.5-0.8 \mathrm{~mL} / \mathrm{kg})$ causes persistent liver injury in rats with inflammation and fibrosis [28, 35] (Fig. 1). Recent studies clearly demonstrate that bone marrow mesenchymal stem cell microvesicles (BM-MSC-MVs) and MSC small extracellular microvesicles (MSC-sEVs) possess anti-fibrotic, anti-inflammatory, and pro-angiogenic properties that can promote the resolution of $\mathrm{CCl}_{4}$-induced liver fibrosis in rats $[29,40]$.

\section{Liver Regeneration Following Surgical Partial Hepatectomy}

Intense regeneration follows a partial hepatectomy involving a $70 \%$ resection in rats and pigs [30-33]. Makino et al. established $90 \%$ hepatectomy as the safety limit for murine hepatectomy and as a model for liver regeneration [34]. Eguchi et al. proposed an alternative model in rats involving resection of the two anterior lobes (68\%) and ligation of the right liver lobes (24\%), stimulating cytokine release following ischemic/reperfusion injury [36].

Several ALF models, such as those using hepatectomy or drug toxicity, have a high mortality rate in the acute phase [37-39], rendering them not perfectly suitable for regeneration studies. Inomata et al. standardized a new treatment using retrorsine (RS) together with partial hepatectomy $(\mathrm{PH})$ in pigs to overcome these limitations. In 2019, Tsuchida et al. studied the engraftment of rat liver organoids derived from fetal livers in an RS/PH rat model. Organoids were injected through the portal vein, which led to liver regeneration and reduced ductular reaction. Remarkably, no translocation to other organs was observed [41].

\section{Genetic Models of Inborn Metabolic Errors}

Several genetic disorders can lead to liver failure, so it is important to use appropriate animal models mimicking human conditions. Hickey et al. developed the first genetically 


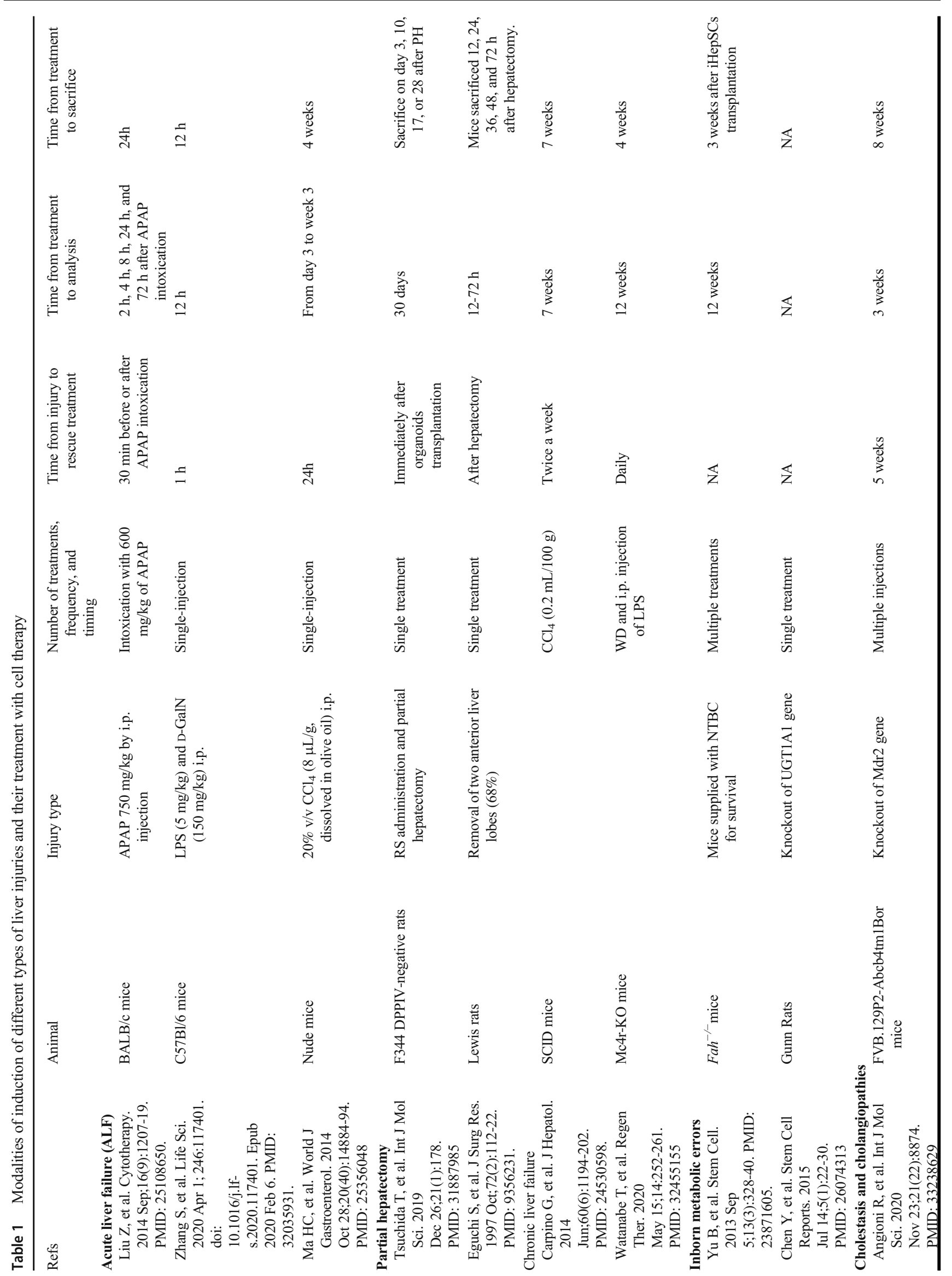




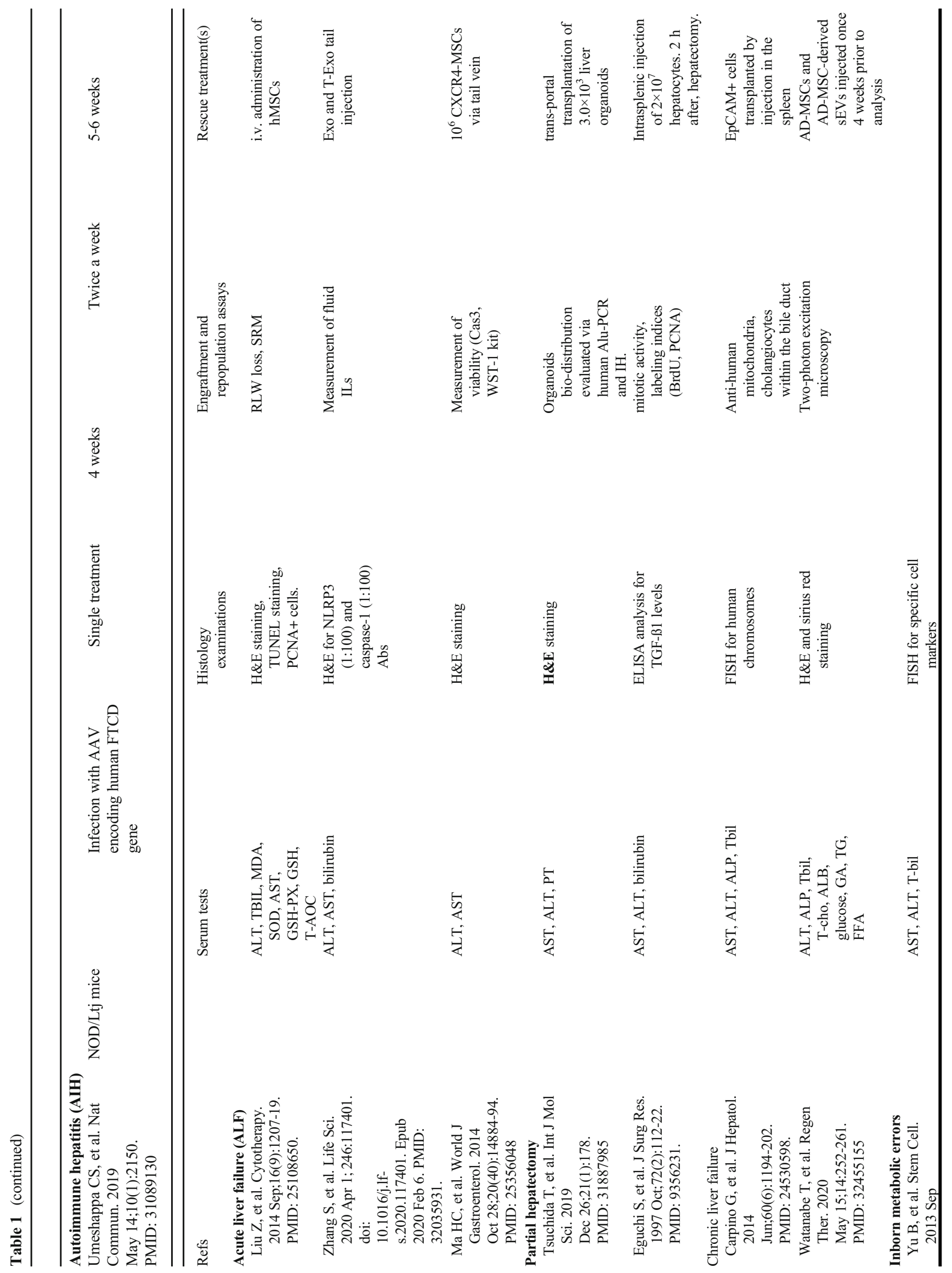




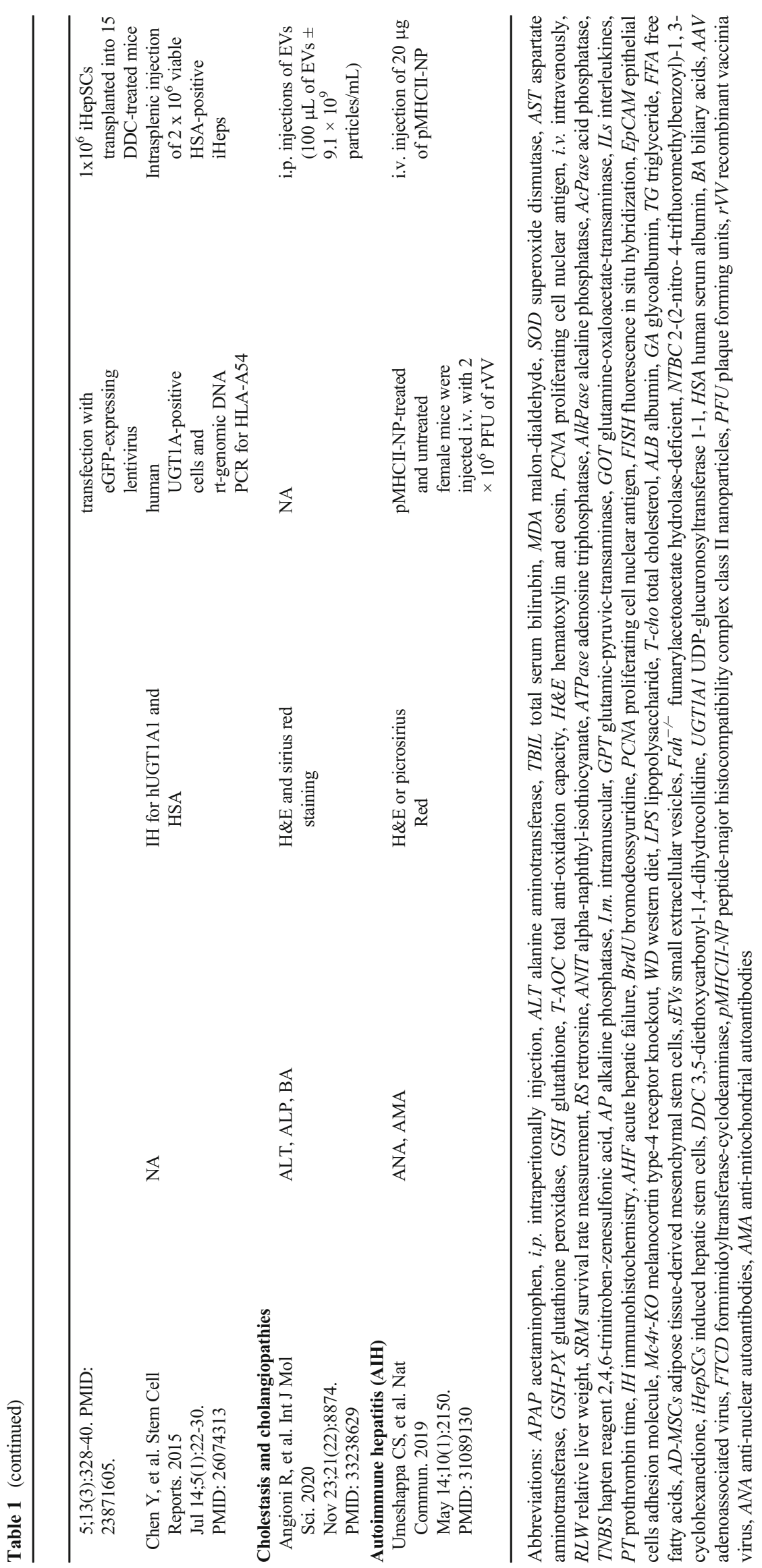


Fig. 1 a Chronic CCl4 administration determinates damage of liver cells and centrilobular congestion with infiltration of inflammatory cells (arrowheads, inset in the lower right corner). The collagen deposition and bridging fibrosis were evident in liver tissue (arrows). b DDC diet induces bile thrombi formation (arrowheads, inset in the lower right corner) and the appearance of extensive KRT19+ ductular reaction (arrows). c MDR-/- mice are characterized by periportal damage (arrowheads) and the development of portal (i.e., biliary) fibrosis (arrows). H\&E, hematoxylin \& eosin; KRT19, keratin 19

a $\mathrm{CCl}_{4}$ Mice

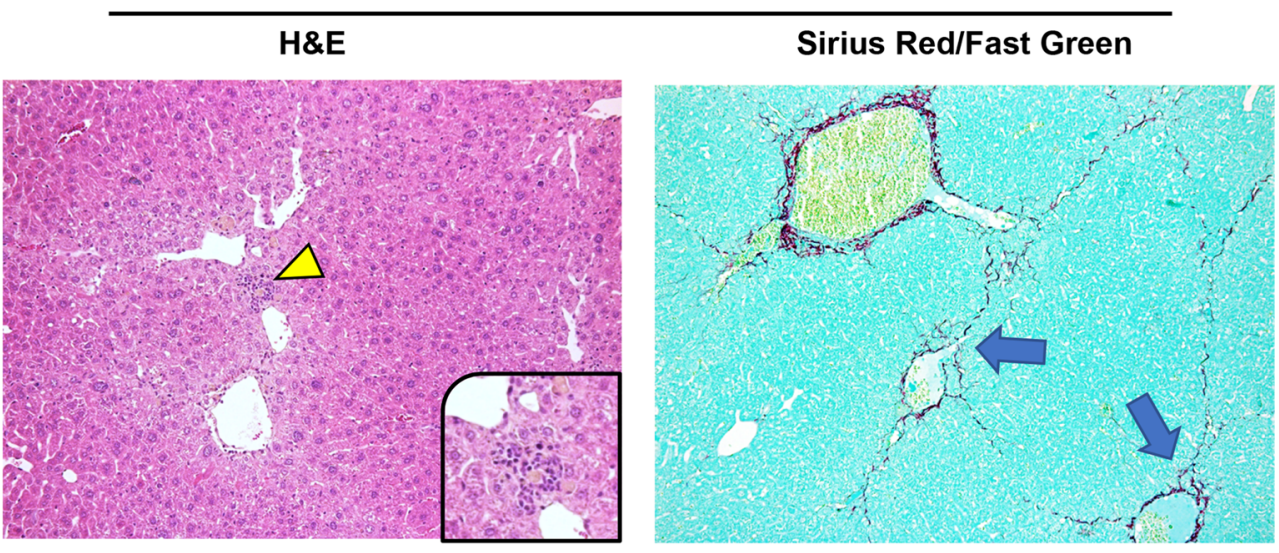

b DDC Mice

H\&E

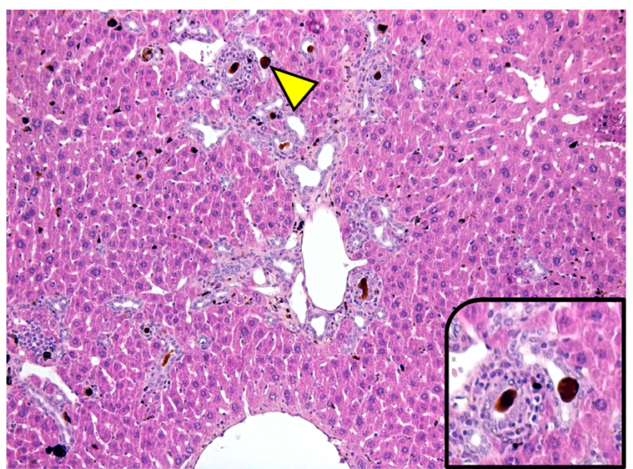

\section{KRT19}

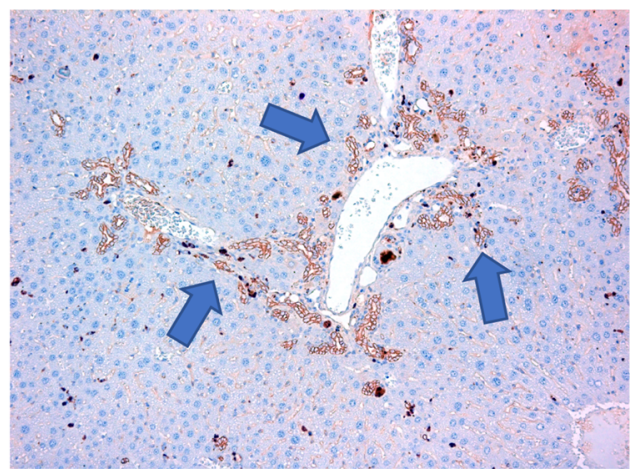

c MDR $^{-1-}$ Mice

\section{H\&E}

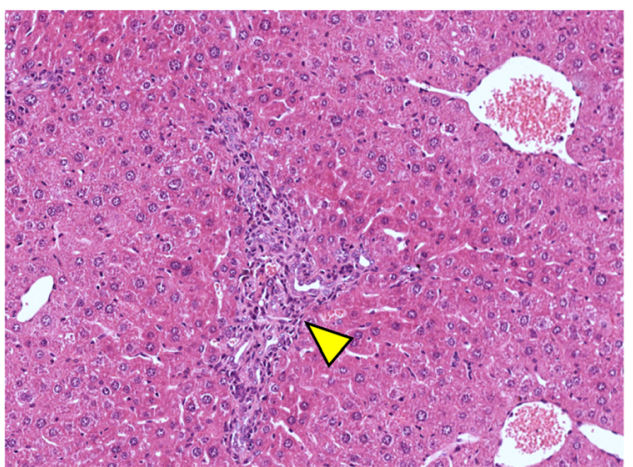

Sirius Red/Fast Green

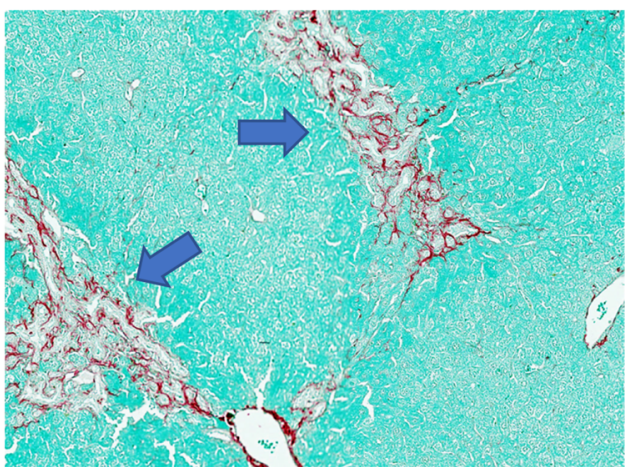

engineered large animal model of a metabolic liver disorder by knocking out fumarylacetoacetate hydrolase (FAH) in pig fibroblasts recapitulating human hereditary tyrosinemia type I (HT1), which results in hepatic failure, cirrhosis, and hepatocellular carcinoma (HCC) in early childhood [42]. Amelioration of this preclinical model involved the administration of 2-(2-nitro-4-trifluoromethylbenzoyl)1,3 cyclohexanedione (NTBC) throughout the pig's pregnancy [43].

In the injured liver of FAH-deficient mice, intrasplenic injection of induced hepatic stem cells derived from mouse embryonic fibroblasts (MEFs) led to differentiation into both 
hepatocytic and cholangiocytic lineages. Induced hepatic stem cells also engraft as cholangiocytes into the bile ducts of mice with 3,5-diethoxycarbonyl-1,4-dihydrocollidine (DDC)-induced bile ductular injury [44].

The Gunn rat is a natural model for bilirubin encephalopathy because it inherently lacks all glucuronidation activity catalyzed by the UDP glucuronosyltransferase 1 (UGT1) isoform [45]. For this reason, these rodents are used as models to study type I Crigler-Najjar (CN) syndrome [46]. In this context, several studies have investigated the effect of humaninduced pluripotent stem cells (iPSCs) in cell therapy. In 2015, it was demonstrated that iPSCs reprogrammed from human skin fibroblasts could differentiate into hepatocytelike cells (iHeps). These cells were transplanted into the livers of Gunn rats and induced a 30-60\% decline in serum bilirubin. Moreover, the excretion of bilirubin glucuronides indicated that transplanted iHeps expressed UGT1A1 activity [47].

Another genetic rat model is the Long-Evans Cinnamon rat, whose mutation mimics human Wilson's disease in terms of excessive copper accumulation in the liver, low levels of serum ceruloplasmin, and low excretion of copper into the bile [48].

\section{Cholestasis and Cholangiopathy Models}

Cholestasis refers to impairment in bile formation or excretion. This can be due to defects in intrahepatic bile production or transmembrane bile transport, or to mechanical bile flow obstruction. Cholangiocytes are hepatic cells that regulate the fluidity and alkalinity of bile through the secretion of osmolytes, such as $\mathrm{Cl}^{-}$and $\mathrm{HCO}_{3}{ }^{-}$. Primary damage to the biliary epithelium causes several chronic cholestatic disorders (cholangiopathies), which are always observed with coexisting cholangiocyte death and proliferation and various degrees of portal inflammation and fibrosis.

The most common experimental rodent model of intrahepatic cholestasis involves the hepatotoxicant molecule known as $\alpha$-Naphthylisothiocyanate (ANIT) $[49,50]$. Recently, FVB.129P2-Abcb4 ${ }^{\text {tm1Bor }}$ mice (FVB.Mdr2 ${ }^{-/-}$) were used as a model for human primary sclerosing cholangitis (PSC) (Fig. 1). These rodents are characterized by the complete inability of the liver to secrete phospholipids into the bile, which results in the spontaneous development of progressive chronic biliary injury and fibrosis [51]. In this context, extracellular vesicles (EVs) isolated from human MSCs have been proposed as a possible effective therapeutic strategy to treat PSC patients [51]. Another mouse model of cholangitis can be obtained by injecting 2-octynoic acid coupled with bovine serum albumin (2OA-BSA) [52]. Fan et al. used this model to prove that human umbilical cordderived MSCs (UC-MSCs) injected intravenously could ameliorate liver inflammation [52].
3,5-Diethoxycarbonyl-1,4-dihydrocollidine (DDC) supplemented diet is an oral (ad libitum) hepatotoxic diet given in mice for 4-8 weeks which determines the formation of intraductal porphyrin plugs, intense ductular reaction, and extrahepatic biliary tree alterations mimicking cholestatic liver diseases and sclerosing cholangitis [1•]. Both chronic inflammation and fibrosis characterize liver parenchyma and bile ducts in this model used for drug discovery and omic studies [1•] (Fig. 1).

\section{Autoimmune Hepatitis Models}

Autoimmune hepatitis (AIH) is a chronic inflammatory disease of the liver characterized by the loss of self-tolerance leading to the appearance of autoantibodies and dysfunction [53]. The first AIH animal models involved the induction of transient hepatitis by immunizing rabbits or mice with complete Freund's adjuvant [54-56]. Other models included endotoxin and plant lectin-induced hepatitis. Tiegs and colleagues first demonstrated that $20 \mathrm{mg} / \mathrm{kg}$ concanavalin A (ConA) induces $\mathrm{T}$ cell-mediated liver damage that is mainly dependent on $\mathrm{CD}^{+} \mathrm{T}$ cells in mice [57]. More recent techniques involve the application of genetic engineering technology [58]. Knocking out specific genes allows ConA models to mimic specific AIH subtypes [53,59]. The most important considerations about these models are (1) the ConA model is a very severe model of liver injury that can lead to high mortality due to severe hemorrhage; and (2) it is difficult to find the antigen of autoantibodies, which is a limitation of the gene-engineered AIH model.

Cell-based therapies are a promising tool for the treatment of AIH. It has recently been highlighted that peptide-major histocompatibility complex class II (pMHCII)-based nanomedicines displaying different cellular epitopes ameliorate AIH conditions without the suppression of host immunity [60].

\section{Routes and Strategies Adopted to Repopulate the Liver and Biliary Tree Through Cell Therapy}

Other factors could influence transplanted cell effectiveness in treating diseased livers, including cell delivery routes and repopulation strategies. These factors alter cellular engraftment and functionality. Therefore, several cell therapy protocols in experimental models were studied to maximize the therapeutic effect of transplanted cells by reducing potential complications [61-64].

In general, cell delivery to the liver could be performed in multiple ways due to its good anatomical accessibility. The vascular route is the most widely used, and cell delivery has 
been performed mainly by injecting cells into the portal vein, hepatic artery, or splenic artery [65-67]. Less relevant approaches involve cell delivery to the liver parenchyma via injection into the intraperitoneal cavity, or through percutaneous tissue $[65,68]$. Although intravenous injection is relatively safe for cell delivery, it is not considered a perfect route because it carries the risk of emboli formation, which could lead to liver infarction, cell damage, or poor cell engraftment due to vascular shear stress $[69,70]$. However, the study by [71••] showed that perfusing cells in a 3D-spheroid form via the intraportal vein could improve cell localization in treated livers, with superior therapeutic benefits in a mouse model. The hepatic artery could provide a better alternative cell delivery route in the presence of portal hypertension-related chronic liver disease [69, 72]. Intrahepatic/parenchymal cell injection is a promising cell delivery strategy, but some complications possibly related to this approach include the risk of injuring parenchymal tissue and blocking the hepatic vascular system or pulmonary capillaries [65].

Developing new modified cell delivery protocols is necessary to achieve more desirable liver cell therapy effects. Intrasplenic injection of hyaluronan-coated hBTSCs in severe combined immunodeficient (SCID) mice showed better cellular engraftment and differentiation into mature hepatocytes [73••]. A recent study by Hwang et al. (2019) coated human adipose-derived stem cells with lipid-conjugated heparin before injecting them via the tail vein into the APAP-induced ALF mouse model and found that this coating method could enhance cell therapy effect on liver damage [74]. The study by Laing et al. found that multipotent adult progenitor cells could be delivered to the donor's liver in vitro via normothermic machine perfusion before liver transplantation to provide the liver with anti-inflammatory and superior immunomodulatory properties [75].

Other strategies to obtain cell therapy effects in liver disease models that do not involve cell transplantation have been tested. These strategies could be performed using cell-free products or derived extracellular nanovesicles, either alone [76] or in combination with transplantable material. A study by Mardpour et al. (2019) tested the intraperitoneal injection of a mixture of polyethylene glycol (PEG) macromeres and MSC-derived extravesicles (MSC-EVs) as a delivery strategy to extend the beneficial effects of cell-free products for a longer time [77]. More research is still needed regarding the effects of different coating materials in the delivery system.

Ongoing studies are needed to compare the different cell delivery approaches in liver disease models with cells of different properties and sizes. Based on the fact that cells can easily be coated or capsulated with natural or synthetic constructs, studies are also needed to evaluate the combination of transplanted cells with different promising materials, scaffolds, or microbeads in order to improve liver cell therapy outcome.

\section{Bioengineered Liver Scaffolds and Their Transplantation}

Bioengineered liver scaffolds aim to generate a highly functional cell delivery system and/or a whole transplantable liver. End-stage liver disease (ESLD) requires radical treatment via liver transplantation in order to save patient lives. However, due to donor shortages and long ESLD patient waiting lists, transplantation surgery may not be available to most patients and it is challenging to find an alternative way to provide transplantable liver scaffolds [78, 79].

Different sources and types of liver scaffolds have been studied in the literature [80-86] (Fig. 2). The most promising and interesting source of liver scaffolds is native hepatic tissue [87-89]. Decellularization of the native livers of lab animals, pigs, and humans has been tested to determine the most suitable and applicable way to generate transplantable bioengineered liver scaffolds [85, 90-92]. Lab animal liver decellularization was studied as a preliminary step to evaluate the gentlest decellularization protocol by characterizing their biochemical components and structural properties as compared with native tissues before testing in larger animals or human tissue [90] (Fig. 2). Pig livers are considered the most readily available source of transplantable scaffolds for preclinical studies and further clinical applications [93-95]. It is worth mentioning that either one liver lobe of an adult pig or the whole liver of a piglet could be suitable for further transplantation [94, 95]. Human liver decellularization is also being investigated as a way to use human livers unable to be transplanted due to the presence of ischemia or other liver diseases. Therefore, decellularization is a good alternative option to increase the number of suitable liver scaffolds that could be recellularized and transplanted $[82,96]$.

Various decellularization protocols have been described for generating a cellular hepatic scaffold. Washing out of cells is mainly performed using chemical detergents such as sodium dodecyl sulfate (SDS) and Triton-X-100, endonuclease enzymes such as DNases, or different combinations of chemicals and enzymes with agitation for liver slices, or by either continuous or pressure-controlled whole liver perfusions [82, 85, 90, 92, 97-99]. Decellularization under oscillating pressure has shown better results in terms of perfusion homogeneity and acellular tissue integrity $[85,92,98,100]$. The main aim of optimizing different decellularization methods is to obtain a balance between the micro/ ultrastructure and remaining DNA level in decellularized tissue [90].

However, many complications are related to the decellularization process, including the loss of some native 
Fig. 2 Possible liver tissue engineering strategies for treating end-stage liver disease

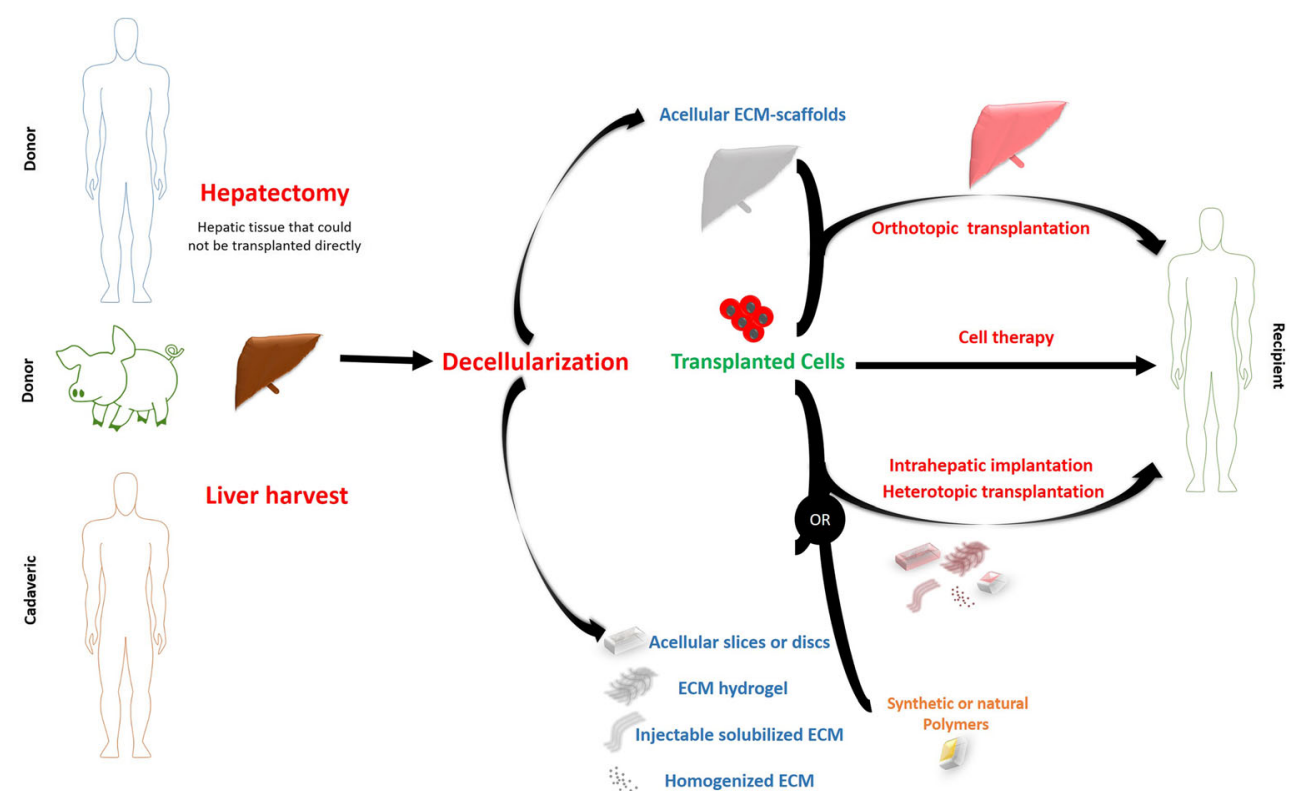

critical components and bioactive molecules. Many studies have investigated how to improve the structural properties of acellular scaffolds through conjugation with crosslinking agents or extracellular matrix (ECM) particles or by improving their functionality with modifying agents that could increase cellular attachment and hemocompatibility, such as CD31, REDV peptide, fibronectin, heparin, and gelatin [80, 84, 93, 101-105]. One study used mice and pig livers that were partially hepatectomized and maintained a few days in vivo before being harvested and decellularized to generate hepatic acellular scaffolds in an active regenerative state. These active scaffolds could be more functional and hemocompatible, with fewer limitations than scaffolds obtained from intact native livers [106].

The native liver-derived ECM can be used as an intact scaffold for further orthotropic or heterotopic transplantation [102, 107, 108]. There are different forms of acellular ECM, including hydrogel, powder, and sheet tissue papers. These forms are fabricated using digested ECM, homogenized ECM, or ECM ink, respectively. These ECM forms could be used for cell delivery, but they have relevant limitations, mainly due to the additional loss of biochemical components during the digestion and fabrication processes [97, 109-116].

Conversely, natural polymers such as collagen and synthetic biodegradable materials have also been studied alone or in combination to generate cell-supporting and functional hepatic scaffolds or cell delivery systems [117-122]. However, these scaffolds could not provide cells with all the bioactive molecules required for their growth as compared with decellularized ECM, which is why synthetic materials were mixed with ECM powder or solubilized ECM to make them more biocompatible and functional. However, many factors regarding the physical and mechanical properties of the synthetic scaffolds should be optimized in order to be approved for clinical application [110, 123].

Cell seeding of acellular hepatic scaffolds was performed mainly via cell perfusion into vascular systems and/or the common bile ducts when using whole decellularized hepatic scaffolds that had intact inlets and outlets, or by direct multiple parenchymal injections, while cells could be laid onto the top surface of hepatic decellularized slices [82, 84, 124-127].

Different cell types could be used for repopulating decellularized livers, including primary hepatocytes, iPSCderived hepatocyte-like cells, stem cells, or mesenchymal stromal cells for recellularization of the parenchymal areas, and endothelial progenitor cells or human umbilical vein endothelial cells (HUVEC) for reendothelization [85, 128-132]. However, optimization of the recellularization process is still a challenge when more than one cell type per scaffold is used.

Recellularized scaffolds could be transplanted after culturing in a bioreactor in vitro for cell differentiation and maturation [131, 133, 134]. The transplantation of recellularized hepatic scaffolds was performed experimentally and preclinically to evaluate biocompatibility and in vivo functionality. Different ways to transplant the recellularized liver constructs were studied to optimize the most effective minimally invasive technique to restore recipient liver function or compensate for the loss of function [61, 82, 87, 103, 135].

To conclude, the most important considerations in generating highly functional cell delivery systems and transplantable hepatic scaffolds include minimizing the deleterious effects of the decellularization process, modifying the acellular scaffolds to overcome existing limitations, and appropriately selecting cells. 
Acknowledgements The Authors kindly thank Dr. Melissa Kerr for english editing of the manuscript.

Author's Contributions All authors contributed to the study conception and design. The first draft of the manuscript was written by GA and TS. Reviewing and editing were completed by VC and GC. All authors commented on the previous versions of the manuscript. All authors read and approved the final manuscript.

Funding Open access funding provided by Università degli Studi di Roma La Sapienza within the CRUI-CARE Agreement.

Data Availability Data and material collection were performed by Gaia Amato and Tarek Saleh.

\section{Declaration}

Ethics Approval and Consent to Participate Not applicable

\section{Consent for Publication Not applicable}

Conflict of Interest The authors declare no conflict of interest

Open Access This article is licensed under a Creative Commons Attribution 4.0 International License, which permits use, sharing, adaptation, distribution and reproduction in any medium or format, as long as you give appropriate credit to the original author(s) and the source, provide a link to the Creative Commons licence, and indicate if changes were made. The images or other third party material in this article are included in the article's Creative Commons licence, unless indicated otherwise in a credit line to the material. If material is not included in the article's Creative Commons licence and your intended use is not permitted by statutory regulation or exceeds the permitted use, you will need to obtain permission directly from the copyright holder. To view a copy of this licence, visit http://creativecommons.org/licenses/by/4.0/.

\section{References}

Papers of particular interest, published recently, have been highlighted as:

- Of importance

•. Of major importance

1. Nevzorova YA, Boyer-Diaz Z, Cubero FJ, Gracia-Sancho J. Animal models for liver disease - a practical approach for translational research. J Hepatol. 2020;73(2):423-40. https://doi.org/ $10.1016 /$ j.jhep.2020.04.011 This review is crucial to understand thecurrent state of research in the field of experimental animal models.

2. Giancotti A, Monti M, Nevi L, Safarikia S, D'Ambrosio V, Brunelli R, et al. Functions and the emerging role of the foetal liver into regenerative medicine. Cells. 2019;8(8):914. https://doi. org/10.3390/cells8080914.

3. Struecker B, Raschzok N, Sauer IM. Liver support strategies: cutting-edge technologies. Nat Rev Gastroenterol Hepatol. 2014;11(3):166-76. https://doi.org/10.1038/nrgastro.2013.204.

4. Lee CA, Sinha S, Fitzpatrick E, Dhawan A. Hepatocyte transplantation and advancements in alternative cell sources for liver-based regenerative medicine. J Mol Med (Berl). 2018;96(6):469-81. https://doi.org/10.1007/s00109-018-1638-5.

5. Newsome PN, Fox R, King AL, Barton D, Than NN, Moore J, et al. Granulocyte colony-stimulating factor and autologous CD133positive stem-cell therapy in liver cirrhosis (REALISTIC): an open-label, randomised, controlled phase 2 trial. Lancet Gastroenterol Hepatol. 2018;3(1):25-36. https://doi.org/10.1016/ S2468-1253(17)30326-6.

6. Lanthier N. Haemopoietic stem cell therapy in cirrhosis: the end of the story? Lancet Gastroenterol Hepatol. 2018;3(1):3-5. https:/ doi.org/10.1016/S2468-1253(17)30359-X.

7. An SY, Jang YJ, Lim HJ, Han J, Lee J, Lee G, et al. Milk fat globule-EGF factor 8 , secreted by mesenchymal stem cells, protects against liver fibrosis in mice. Gastroenterology. 2017;152(5): 1174-86. https://doi.org/10.1053/j.gastro.2016.12.003.

8. Starkey Lewis P, Campana L, Aleksieva N, Cartwright JA, Mackinnon A, O'Duibhir E, et al. Alternatively activated macrophages promote resolution of necrosis following acute liver injury. J Hepatol. 2020;73(2):349-60. https://doi.org/10.1016/j.jhep. 2020.02.031.

9. Bernal W, Auzinger G, Dhawan A, Wendon J. Acute liver failure. Lancet. 2010;376(9736):190-201. https://doi.org/10.1016/S01406736(10)60274-7.

10. O'Grady JG, Schalm SW, Williams ER. Acute liver failure: redefining the syndromes. Lancet Lond Engl. 1993;342(8866): 273-5. https://doi.org/10.1016/0140-6736(93)91818-7.

11. Boxill GC, Nash CB, Wheeler EAG. Comparative pharmacological and toxicological evaluation of $\mathrm{N}$-acetyl-p-aminophenol, salicylamide, and acetylsalicylic acid. J Am Pharm Assoc Sci Ed. 1958;47(7):479-87. https://doi.org/10.1002/jps.3030470706.

12. Eder H. Chronic toxicity studies on phenacetin, N-acetyl-paminophenol (napa) and acetylsalicylic acid on cats. Acta Pharmacol Toxicol (Copenh.). 1964;21:197-204. https://doi.org/ 10.1111/j.1600-0773.1964.tb01784.x.

13. McGill MR, Williams CD, Xie Y, Ramachandran A, Jaeschke EH. Acetaminophen-induced liver injury in rats and mice: comparison of protein adducts, mitochondrial dysfunction, and oxidative stress in the mechanism of toxicity. Toxicol Appl Pharmacol. 2012;264(3):387-94. https://doi.org/10.1016/j.taap.2012.08.015.

14. Liu Z, et al. Human umbilical cord mesenchymal stromal cells rescue mice from acetaminophen-induced acute liver failure. Cytotherapy. 2014;16(9):1207-19. https://doi.org/10.1016/j.jcyt. 2014.05.018.

15. Jaeschke H, Fisher MA, Lawson JA, Simmons CA, Farhood A, Jones EDA. Activation of caspase 3 (CPP32)-like proteases is essential for TNF-alpha-induced hepatic parenchymal cell apoptosis and neutrophil-mediated necrosis in a murine endotoxin shock model. J Immunol Baltim Md 1950. 1998;160(7):3480-86.

16. Leist M, Gantner F, Jilg S, Wendel A. Activation of the $55 \mathrm{kDa}$ TNF receptor is necessary and sufficient for TNF-induced liver failure, hepatocyte apoptosis, and nitrite release. J Immunol Baltim Md 1950. 1995;154(3):1307-16.

17. Gujral JS, Hinson JA, Farhood A, Jaeschke H. NADPH oxidasederived oxidant stress is critical for neutrophil cytotoxicity during endotoxemia. Am J Physiol Gastrointest Liver Physiol. 2004;287(1):G243-52. https://doi.org/10.1152/ajpgi.00287.2003.

18. Choi J-H, Kang J-W, Kim D-W, Sung Y-K, Lee S-M. Protective effects of Mg-CUD against d-galactosamine-induced hepatotoxicity in rats. Eur J Pharmacol. 2011;657(1):138-43. https://doi.org/ 10.1016/j.ejphar.2011.01.030.

19. González R, et al. N-acetylcysteine, coenzyme Q10 and superoxide dismutase mimetic prevent mitochondrial cell dysfunction and cell death induced by d-galactosamine in primary culture of human hepatocytes. Chem Biol Interact. 2009;181(1):95-106. https://doi.org/10.1016/j.cbi.2009.06.003. 
20. Nolan JP. The role of intestinal endotoxin in liver injury: a long and evolving history. Hepatology. 2010;52(5):1829-35. https:// doi.org/10.1002/hep.23917.

21. Maes M, Vinken M, Jaeschke H. Experimental models of hepatotoxicity related to acute liver failure. Toxicol Appl Pharmacol. 2016;290:86-97. https://doi.org/10.1016/j.taap.2015.11.016.

22. Zhang S, et al. Pretreatment of exosomes derived from hUCMSCs with TNF- $\alpha$ ameliorates acute liver failure by inhibiting the activation of NLRP3 in macrophage. Life Sci. 2020;246:117401. https://doi.org/10.1016/j.lfs.2020.117401.

23. Gao J, Dennis JE, Muzic RF, Lundberg M, Caplan AI. The dynamic in vivo distribution of bone marrow-derived mesenchymal stem cells after infusion. Cells Tissues Organs. 2001;169(1):1220. https://doi.org/10.1159/000047856.

24. Ma H-C, Shi X-L, Ren H-Z, Yuan X-W, Ding Y-T. Targeted migration of mesenchymal stem cells modified with CXCR4 to acute failing liver improves liver regeneration. World $\mathrm{J}$ Gastroenterol WJG. 2014;20(40):14884-94. https://doi.org/10. 3748/wjg.v20.i40.14884.

25. Chakraborty JB, Oakley F, Walsh MJ. Mechanisms and biomarkers of apoptosis in liver disease and fibrosis. Int J Hepatol. 2012;2012:648915. https://doi.org/10.1155/2012/648915.

26. Seyan AS, Hughes RD, Shawcross DL. Changing face of hepatic encephalopathy: role of inflammation and oxidative stress. World J Gastroenterol. 2010;16(27):3347-57. https://doi.org/10.3748/ wjg.v16.i27.3347.

27. Pinzani M, Rosselli M, Zuckermann M. Liver cirrhosis. Best Pract Res Clin Gastroenterol. 2011;25(2):281-90. https://doi.org/10. 1016/j.bpg.2011.02.009.

28. McGill MR, Jaeschke H. Animal models of drug-induced liver injury. Biochim Biophys Acta BBA - Mol Basis Dis. 2019;1865(5):1031-9. https://doi.org/10.1016/j.bbadis.2018.08. 037.

29. Sabry D, Mohamed A, Monir M, Ibrahim HA. The effect of mesenchymal stem cells derived microvesicles on the treatment of experimental CCL4 induced liver fibrosis in rats. Int J Stem Cells. 2019;12(3):400-9. https://doi.org/10.15283/ijsc18143.

30. Kahn D, Hickman R, Terblanche J, von Sommoggy S. Partial hepatectomy and liver regeneration in pigs-the response to different resection sizes. J Surg Res. 1988;45(2):176-80. https://doi. org/10.1016/0022-4804(88)90062-5.

31. Emond J, Capron-Laudereau M, Meriggi F, Bernuau J, Reynes M, Houssin D. Extent of hepatectomy in the rat. Evaluation of basal conditions and effect of therapy. Eur Surg Res. 1989;21(5):251-9. https://doi.org/10.1159/000129034.

32. Tonnesen K. Experimental liver failure. A comparison between hepatectomy and hepatic devascularization in the pig. Acta Chir Scand. 1977;143(5):271-7.

33. Panis Y, McMullan DM, Emond JC. Progressive necrosis after hepatectomy and the pathophysiology of liver failure after massive resection. Surgery. 1997;121(2):142-9. https://doi.org/10.1016/ s0039-6060(97)90283-x.

34. Makino $\mathrm{H}$, et al. A good model of hepatic failure after excessive hepatectomy in mice. J. Surg. Res. 2005;127(2):171-6. https://doi. org/10.1016/j.jss.2005.04.029.

35. Carpino G, Cardinale V, Gentile R, Onori P, Semeraro R, Franchitto A, et al. Evidence for multipotent endodermal stem/ progenitor cell populations in human gallbladder. J Hepatol. 2014;60(6):1194-202. https://doi.org/10.1016/j.jhep.2014.01. 026.

36. Eguchi S, Lilja H, Hewitt WR, Middleton Y, Demetriou AA, Rozga J. Loss and recovery of liver regeneration in rats with fulminant hepatic failure. J Surg Res. 1997;72(2):112-22. https://doi. org/10.1006/jsre.1997.5175.

37. Newsome PN, et al. Development of an invasively monitored porcine model of acetaminophen-induced acute liver failure.
BMC Gastroenterol. 2010;10(1):34. https://doi.org/10.1186/ 1471-230X-10-34

38. Arkadopoulos N, et al. Development of a porcine model of posthepatectomy liver failure. J Surg Res. 2011;170(2):e233-42. https://doi.org/10.1016/j.jss.2011.06.006.

39. Sielaff TD, et al. An anesthetized model of lethal canine galactosamine fulminant hepatic failure. Hepatol Baltim Md. 1995;21(3): 796-804.

40. Watanabe T, Tsuchiya A, Takeuchi S, Nojiri S, Yoshida T, Ogawa $\mathrm{M}$, et al. Development of a non-alcoholic steatohepatitis model with rapid accumulation of fibrosis, and its treatment using mesenchymal stem cells and their small extracellular vesicles. Regen Ther. 2020;14:252-61. https://doi.org/10.1016/j.reth.2020.03. 012.

41. Tsuchida $\mathrm{T}$, et al. The regenerative effect of portal vein injection of liver organoids by retrorsine/partial hepatectomy in rats. Int J Mol Sci. 2019;21:1. https://doi.org/10.3390/ijms21010178.

42. Hickey RD, et al. Efficient production of Fah-null heterozygote pigs by chimeric adeno-associated virus-mediated gene knockout and somatic cell nuclear transfer. Hepatol Baltim Md. 2011;54(4): 1351-9. https://doi.org/10.1002/hep.24490.

43. Hickey RD, et al. Fumarylacetoacetate hydrolase deficient pigs are a novel large animal model of metabolic liver disease. Stem Cell Res. 2014;13(1):144-53. https://doi.org/10.1016/j.scr.2014.05. 003.

44. $\mathrm{Yu} \mathrm{B}$, et al. Reprogramming fibroblasts into bipotential hepatic stem cells by defined factors. Cell Stem Cell. 2013;13(3):328-40. https://doi.org/10.1016/j.stem.2013.06.017.

45. Iyanagi T. Molecular basis of multiple UDP-glucuronosyltransferase isoenzyme deficiencies in the hyperbilirubinemic rat (Gunn rat). J Biol Chem. 1991;266(35):24048-52. https://doi.org/10. 1016/S0021-9258(18)54390-8.

46. Chowdhury JR, Kondapalli R, Chowdhury NR. Gunn rat: a model for inherited deficiency of bilirubin glucuronidation. Adv Vet Sci Comp Med. 1993;37:149-73.

47. Chen Y, et al. Amelioration of hyperbilirubinemia in Gunn Rats after transplantation of human induced pluripotent stem cell-derived hepatocytes. Stem Cell Rep. 2015;5(1):22-30. https://doi. org/10.1016/j.stemcr.2015.04.017.

48. Yamada T, Agui T, Suzuki Y, Sato M, Matsumoto K. Inhibition of the copper incorporation into ceruloplasmin leads to the deficiency in serum ceruloplasmin activity in Long-Evans cinnamon mutant rat. J Biol Chem. 1993;268(12):8965-71.

49. Simon FR, Fortune J, Iwahashi M, Gartung C, Wolkoff A, Sutherland E. Ethinyl estradiol cholestasis involves alterations in expression of liver sinusoidal transporters. Am J Physiol. 1996;271(6 Pt 1):G1043-52. https://doi.org/10.1152/ajpgi.1996. 271.6.G1043.

50. De Vos R, Desmet V. Morphology of liver cell tight junctions in ethinyl estradiol induced cholestasis. Pathol Res Pract. 1981;171(3-4):381-8. https://doi.org/10.1016/S0344-0338(81) 80111-2.

51. Angioni R, et al. Administration of human MSC-derived extracellular vesicles for the treatment of primary sclerosing cholangitis: preclinical data in MDR2 knockout mice. Int J Mol Sci. 2020;21: 22. https://doi.org/10.3390/ijms21228874.

52. Fan J, et al. Mesenchymal stem cells alleviate experimental autoimmune cholangitis through immunosuppression and cytoprotective function mediated by galectin- 9 . Stem Cell Res Ther. 2018;9(1):237. https://doi.org/10.1186/s13287-018-0979-x.

53. Wang H-X, et al. Immune mechanisms of concanavalin A model of autoimmune hepatitis. World J Gastroenterol. 2012;18(2):119 25. https://doi.org/10.3748/wjg.v18.i2.119.

54. Büschenfelde KH, Kössling FK, Miescher PA. Experimental chronic active hepatitis in rabbits following immunization with human liver proteins. Clin Exp Immunol. 1972;11(1):99-108. 
55. Mihas AA, Subramony C, Achord JL. Experimental autoimmune hepatitis in mice following immunization with syngeneic liver proteins. J Med. 1995;26(5-6):309-22.

56. Lohse AW, Manns M, Dienes HP, Büschenfelde KHMZ, Cohen IR. Experimental autoimmune hepatitis: disease induction, time course and T-cell reactivity. Hepatol Baltim Md. 1990;11(1):24 30. https://doi.org/10.1002/hep.1840110106.

57. Tiegs G, Hentschel J, Wendel A. A T cell-dependent experimental liver injury in mice inducible by concanavalin A. J Clin Invest. 1992;90(1):196-203. https://doi.org/10.1172/JCI115836.

58. El Hefnawi MM, El Behaidy WH, Youssif AA, Ghalwash AZ, El Housseiny LA, Zada S. Natural genetic engineering of hepatitis $C$ virus NS5A for immune system counterattack. Ann N Y Acad Sci. 2009;1178:173-85. https://doi.org/10.1111/j.1749-6632.2009. 05003.x.

59. Pearson T, Greiner DL, Shultz LD. Creation of "humanized" mice to study human immunity. Curr Protoc Immunol, Chapter 15, pag. Unit 15.21. 2008. https://doi.org/10.1002/0471142735. im1521s 81

60. Umeshappa CS, Singha S, Blanco J, Shao K, Nanjundappa RH, Yamanouchi J, et al. Suppression of a broad spectrum of liver autoimmune pathologies by single peptide-MHC-based nanomedicines. Nat Commun. 2019;10(1):2150. https://doi.org/ 10.1038/s41467-019-09893-5.

61. Acun A, Oganesyan R, Uygun BE. Liver bioengineering: promise, pitfalls, and hurdles to overcome. Curr Transplant Rep. 2019;6(2):119-26. https://doi.org/10.1007/s40472-019-00236-3.

62. Alfaifi M, Eom YW, Newsome PN, Baik SK. Mesenchymal stromal cell therapy for liver diseases. J. Hepatol. 2018;68(6):127285. https://doi.org/10.1016/j.jhep.2018.01.030.

63. Alwahsh SM, Rashidi H, Hay DC. Liver cell therapy: is this the end of the beginning? Cell Mol Life Sci CMLS. 2018;75(8):130724. https://doi.org/10.1007/s00018-017-2713-8.

64. Kwak K-A, Cho H-J, Yang J-Y, Park Y-S. Current perspectives regarding stem cell-based therapy for liver cirrhosis. Can J Gastroenterol Hepatol. 2018, 2018:4197857. https://doi.org/10. 1155/2018/4197857.

65. Forbes SJ, Gupta S, Dhawan A. Cell therapy for liver disease: from liver transplantation to cell factory. J Hepatol. 2015;62(1 Suppl):S157-69. https://doi.org/10.1016/j.jhep.2015.02.040.

66. Nagata H, Ito M, Shirota C, Edge A, McCowan TC, Fox IJ. Route of hepatocyte delivery affects hepatocyte engraftment in the spleen. Transplantation. 2003;76(4):732-4. https://doi.org/10. 1097/01.TP.0000081560.16039.67.

67. Shiota G, Itaba N. Progress in stem cell-based therapy for liver disease. Hepatol Res Off J Jpn Soc Hepatol. 2017;47(2):127-41. https://doi.org/10.1111/hepr.12747.

68. Jitraruch S, et al. Cryopreservation of hepatocyte microbeads for clinical transplantation. Cell Transplant. 2017;26(8):1341-54. https://doi.org/10.1177/0963689717720050.

69. Dwyer BJ, Macmillan MT, Brennan PN, Forbes SJ. Cell therapy for advanced liver diseases: repair or rebuild. J. Hepatol. 2020. https://doi.org/10.1016/j.jhep.2020.09.014.

70. Habeeb MA, Vishwakarma SK, Bardia A, Khan AA. Hepatic stem cells: a viable approach for the treatment of liver cirrhosis. World J Stem Cells. 2015;7(5):859-65. https://doi.org/10.4252/ wjsc.v7.i5.859.

71.• Regmi S, et al. Intraportally delivered stem cell spheroids localize in the liver and protect hepatocytes against GalN/LPS-induced fulminant hepatic toxicity. Stem Cell Res Ther. 2019;10(1):230. https://doi.org/10.1186/s13287-019-1337-3 Suggests that the intraportal transplantation of 3D spheroids of adiposederived mesenchymal stem cells could localize in the liver and ameliorate GalN/LPS-induced FHF

72. Wu C-X, Wang D, Cai Y, Luo A-R, Sun H. Effect of autologous bone marrow stem cell therapy in patients with liver cirrhosis: a meta-analysis. J Clin Transl Hepatol. 2019;7(3):238-48. https:// doi.org/10.14218/JCTH.2019.00008.

73.• Nevi L, et al. Hyaluronan coating improves liver engraftment of transplanted human biliary tree stem/progenitor cells. Stem Cell Res Ther 2017;8(1):68. https://doi.org/10.1186/s13287-0170492-7 This study develops an easily applicable method to coat hBTSCs with HA and showed great improvements in the cellular properties in terms of viability, engraftment, and differentiation.

74. Hwang Y, Kim JC, Tae G. Significantly enhanced recovery of acute liver failure by liver targeted delivery of stem cells via heparin functionalization. Biomaterials. 2019;209:67-78. https://doi. org/10.1016/j.biomaterials.2019.04.019.

75. Laing RW, et al. The delivery of multipotent adult progenitor cells to extended criteria human donor livers using normothermic machine perfusion. Front Immunol. 2020;11:1226. https://doi.org/10. 3389/fimmu.2020.01226.

76. Han HS, et al. Human adipose stem cell-derived extracellular nanovesicles for treatment of chronic liver fibrosis. J Control Release. 2020;320:328-36. https://doi.org/10.1016/j.jconrel. 2020.01.042

77. Mardpour S, et al. Hydrogel-mediated sustained systemic delivery of mesenchymal stem cell-derived extracellular vesicles improves hepatic regeneration in chronic liver failure. ACS Appl Mater Interfaces. 2019;11(41):37421-33. https://doi.org/10.1021/ acsami.9b10126.

78. Li Y, Wu Q, Wang Y, Bu H, Bao J. Porcine hepatocytes: isolation and liver tissue engineering for xenotransplantation. Methods Mol. Biol. Clifton NJ. 2020;2110:267-87. https://doi.org/10. 1007/978-1-0716-0255-3_18.

79. Rossi EA, Quintanilha LF, Nonaka CKV, Souza BS de F. Advances in hepatic tissue bioengineering with decellularized liver bioscaffold. Stem Cells Int. 2019;2693189. https://doi.org/10. $1155 / 2019 / 2693189$

80. Gao M, et al. Comparative evaluation of decellularized porcine liver matrices crosslinked with different chemical and natural crosslinking agents. Xenotransplantation. 2019;26(1):e12470. https://doi.org/10.1111/xen.12470.

81. Jakus AE, et al. "Tissue Papers" from organ-specific decellularized extracellular matrices. Adv Funct Mater. 2017;27: 3. https://doi.org/10.1002/adfm.201700992.

82. Mazza G, et al. Decellularized human liver as a natural 3D-scaffold for liver bioengineering and transplantation. Sci Rep. 2015;5: 13079. https://doi.org/10.1038/srep13079.

83. Rajalekshmi R, Kaladevi Shaji A, Joseph R, Bhatt A. Scaffold for liver tissue engineering: exploring the potential of fibrin incorporated alginate dialdehyde-gelatin hydrogel. Int J Biol Macromol. 2020. https://doi.org/10.1016/j.ijbiomac.2020.10.256.

84. Saleh T, et al. Silver nanoparticles improve structural stability and biocompatibility of decellularized porcine liver. Artif. Cells Nanomed Biotechnol. 2018;46(sup2):273-84. https://doi.org/10. 1080/21691401.2018.1457037.

85. Willemse J, et al. Fast, robust and effective decellularization of whole human livers using mild detergents and pressure controlled perfusion. Mater Sci Eng C Mater Biol Appl. 2020;108:110200. https://doi.org/10.1016/j.msec.2019.110200.

86. Ye S, Boeter JWB, Penning LC, Spee B, Schneeberger K. Hydrogels for liver tissue engineering. Bioeng. Basel Switz. 2019;6:3. https://doi.org/10.3390/bioengineering6030059.

87. Shimoda H, et al. Decellularized liver scaffolds promote liver regeneration after partial hepatectomy. Sci. Rep. 2019;9(1): 12543. https://doi.org/10.1038/s41598-019-48948-x.

88. Swinehart IT, Badylak SF. Extracellular matrix bioscaffolds in tissue remodeling and morphogenesis. Dev Dyn Off Publ Am Assoc Anat. 2016;245(3):351-60. https://doi.org/10.1002/dvdy. 24379. 
89. Willemse J, Lieshout R, van der Laan LJW, Verstegen MMA. From organoids to organs: bioengineering liver grafts from hepatic stem cells and matrix. Best Pract Res Clin Gastroenterol. 2017;31(2):151-9. https://doi.org/10.1016/j.bpg.2017.03.003.

90. Ahmed E, et al. Micro and ultrastructural changes monitoring during decellularization for the generation of a biocompatible liver. J Biosci Bioeng. 2019;128(2):218-25. https://doi.org/10.1016/ j.jbiosc.2019.02.007.

91. Bühler NEM, Schulze-Osthoff K, Königsrainer A, Schenk M. Controlled processing of a full-sized porcine liver to a decellularized matrix in 24 h. J Biosci Bioeng. 2015;119(5): 609-13. https://doi.org/10.1016/j.jbiosc.2014.10.019.

92. Struecker B, et al. Porcine liver decellularization under oscillating pressure conditions: a technical refinement to improve the homogeneity of the decellularization process. Tissue Eng Part C Methods. 2015;21(3):303-13. https://doi.org/10.1089/ten.TEC. 2014.0321

93. Bao J, et al. Hemocompatibility improvement of perfusiondecellularized clinical-scale liver scaffold through heparin immobilization. Sci Rep. 2015;5:10756. https://doi.org/10.1038/ srep10756.

94. Barakat $\mathrm{O}$, et al. Use of decellularized porcine liver for engineering humanized liver organ. J Surg Res. 2012;173(1):e11-25. https://doi.org/10.1016/j.jss.2011.09.033.

95. Ko IK, et al. Bioengineered transplantable porcine livers with reendothelialized vasculature. Biomaterials. 2015;40:72-9. https:// doi.org/10.1016/j.biomaterials.2014.11.027.

96. Mattei G, Magliaro C, Pirone A, Ahluwalia A. Decellularized human liver is too heterogeneous for designing a generic extracellular matrix mimic hepatic scaffold. Artif Organs. 2017;41(12): E347-55. https://doi.org/10.1111/aor.12925.

97. Coronado RE, Somaraki-Cormier M, Natesan S, Christy RJ, Ong JL, Halff GA. Decellularization and solubilization of porcine liver for use as a substrate for porcine hepatocyte culture: method optimization and comparison. Cell Transplant. 2017;26(12):1840-54. https://doi.org/10.1177/0963689717742157.

98. Verstegen MMA, et al. Decellularization of whole human liver grafts using controlled perfusion for transplantable organ bioscaffolds. Stem Cells Dev. 2017;26(18):1304-15. https://doi. org $/ 10.1089 / \mathrm{scd} .2017 .0095$.

99. Wang Y, et al. Method for perfusion decellularization of porcine whole liver and kidney for use as a scaffold for clinical-scale bioengineering engrafts. Xenotransplantation. 2015;22(1):48-61. https://doi.org/10.1111/xen.12141.

100. Mazza G, et al. Rapid production of human liver scaffolds for functional tissue engineering by high shear stress oscillationdecellularization. Sci Rep. 2017;7(1):5534. https://doi.org/10. 1038/s41598-017-05134-1.

101. Devalliere J, Chen Y, Dooley K, Yarmush ML, Uygun BE. Improving functional re-endothelialization of acellular liver scaffold using REDV cell-binding domain. Acta Biomater. 2018;78: 151-64. https://doi.org/10.1016/j.actbio.2018.07.046.

102. Meng F, Almohanna F, Altuhami A, Assiri AM, Broering D. Vasculature reconstruction of decellularized liver scaffolds via gelatin-based re-endothelialization. J Biomed Mater Res A. 2019;107(2):392-402. https://doi.org/10.1002/jbm.a.36551.

103. Saleh T, et al. Conjugating homogenized liver-extracellular matrix into decellularized hepatic scaffold for liver tissue engineering. J Biomed Mater Res A. 1991-2004;108(10):2020. https://doi.org/ 10.1002/jbm.a.36920.

104. Wang Y, et al. Genipin crosslinking reduced the immunogenicity of xenogeneic decellularized porcine whole-liver matrices through regulation of immune cell proliferation and polarization. Sci Rep. 2016;6:24779. https://doi.org/10.1038/srep24779.
105. Watanabe M, et al. Construction of sinusoid-scale microvessels in perfusion culture of a decellularized liver. Acta Biomater. 2019;95:307-18. https://doi.org/10.1016/j.actbio.2018.12.042.

106. Yang W, et al. A novel bioscaffold with naturally-occurring extracellular matrix promotes hepatocyte survival and vessel patency in mouse models of heterologous transplantation. Biomaterials. 2018;177:52-66. https://doi.org/10.1016/j.biomaterials.2018.05. 026.

107. Bruinsma BG, Kim Y, Berendsen TA, Ozer S, Yarmush ML, Uygun BE. Layer-by-layer heparinization of decellularized liver matrices to reduce thrombogenicity of tissue engineered grafts. J Clin Transl Res. 2015;1(1):48-56.

108. Zhang H, Zhang Y, Ma F, Bie P, Bai L. Orthotopic transplantation of decellularized liver scaffold in mice. Int J Clin Exp Med. 2015;8(1):598-606.

109. Ahmed E, et al. Decellularized extracellular matrix-rich hydrogelsilver nanoparticle mixture as a potential treatment for acute liver failure model. J Biomed Mater Res A. 2020;108(12):2351-67. https://doi.org/10.1002/jbm.a.36988.

110. Damania A, et al. Decellularized liver matrix-modified cryogel scaffolds as potential hepatocyte carriers in bioartificial liver support systems and implantable liver constructs. ACS Appl Mater Interfaces. 2018;10(1):114-26. https://doi.org/10.1021/acsami. $7 \mathrm{~b} 13727$.

111. Ijima H, Nakamura S, Bual RP, Yoshida K. Liver-specific extracellular matrix hydrogel promotes liver-specific functions of hepatocytes in vitro and survival of transplanted hepatocytes in vivo. J Biosci Bioeng. 2019;128(3):365-72. https://doi.org/10.1016/j. jbiosc.2019.02.014.

112. $\mathrm{Li} \mathrm{Y}$, et al. Heterotopic vascularization and functionalization of implantable bio engineered hepatic tissue alleviates liver injury in rats. Liver Int Off J Int. Assoc Study Liver. 2020;40(3):712-26. https://doi.org/10.1111/liv.14267.

113. Nakatsuji H, Kitano S, Irie S, Matsusaki M. Preparation of extracellular matrix paper and construction of multi-layered 3D tissue model. Curr Protoc Cell Biol. 2020;88(1):e112. https://doi.org/10. 1002/cpcb.112.

114. Nakatsuji H, Matsusaki M. Extracellular matrix microfiber papers for constructing multilayered 3D composite tissues. ACS Biomater Sci Eng. 2019;5(11):5610-4. https://doi.org/10.1021/ acsbiomaterials.9b00090.

115. Nobakht Lahrood F, et al. Generation of transplantable three-dimensional hepatic-patch to improve the functionality of hepatic cells in vitro and in vivo. Stem Cells Dev. 2020;29(5):301-13. https://doi.org/10.1089/scd.2019.0130.

116. Prior N, Inacio P, Huch M. Liver organoids: from basic research to therapeutic applications. Gut. 2019;68(12):2228-37. https://doi. org/10.1136/gutjnl-2019-319256.

117. Das P, DiVito MD, Wertheim JA, Tan LP. Collagen-I and fibronectin modified three-dimensional electrospun PLGA scaffolds for long-term in vitro maintenance of functional hepatocytes. Mater Sci Eng C Mater Biol Appl. 2020;111:110723. https://doi. org/10.1016/j.msec.2020.110723.

118. Kaur S, Tripathi D, Venugopal J, Ramakrishna S. Advances in biomaterials for hepatic tissue engineering. Curr Opin Biomed Eng. 2020;13. https://doi.org/10.1016/j.cobme.2020.05.005.

119. Lee H-J, et al. Optimization of 3D hydrogel microenvironment for enhanced hepatic functionality of primary human hepatocytes. Biotechnol Bioeng. 2020;117(6):1864-76. https://doi.org/10. 1002/bit.27328.

120. Luo H, Cha R, Li J, Hao W, Zhang Y, Zhou F. Advances in tissue engineering of nanocellulose-based scaffolds: a review. Carbohydr Polym. 2019;224:115144. https://doi.org/10.1016/j. carbpol.2019.115144.

121. Qiu R, Murata S, Oshiro K, Hatada Y, Taniguchi H. Transplantation of fetal liver tissue coated by ultra-purified 
alginate gel over liver improves hepatic function in the cirrhosis rat model. Sci Rep. 2020;10(1):8231. https://doi.org/10.1038/ s41598-020-65069-y.

122. Ye S, et al. A chemically defined hydrogel for human liver organoid culture. Adv. Funct. Mater. 2020;30(48):2000893. https://doi.org/10.1002/adfm.202000893.

123. Agarwal T, Maiti TK, Behera B, Ghosh SK, Apoorva A, Padmavati M. Biofunctionalized cellulose paper matrix for cell delivery applications. Int J Biol Macromol. 2019;139:114-27. https://doi.org/10.1016/j.ijbiomac.2019.07.201.

124. Croce S, Peloso A, Zoro T, Avanzini MA, Cobianchi L. A hepatic scaffold from decellularized liver tissue: food for thought. Biomolecules. 2019;9:12. https://doi.org/10.3390/biom9120813.

125. Kojima $\mathrm{H}$, et al. Establishment of practical recellularized liver graft for blood perfusion using primary rat hepatocytes and liver sinusoidal endothelial cells. Am J Transplant. 2018;18(6):1351-9. https://doi.org/10.1111/ajt.14666.

126. Ogiso S, et al. Efficient recellularisation of decellularised wholeliver grafts using biliary tree and foetal hepatocytes. Sci Rep. 2016;6:35887. https://doi.org/10.1038/srep35887.

127. Soto-Gutierrez A, et al. A whole-organ regenerative medicine approach for liver replacement. Tissue Eng Part C Methods. 2011;17(6):677-86. https://doi.org/10.1089/ten.TEC.2010.0698.

128. Chen Y, Geerts S, Jaramillo M, Uygun BE. Preparation of decellularized liver scaffolds and recellularized liver grafts. Methods Mol Biol Clifton NJ. 2018;1577:255-70. https://doi. org/10.1007/7651_2017_56.

129. Debnath T, Mallarpu CS, Chelluri LK. Development of bioengineered organ using biological acellular rat liver scaffold and hepatocytes. Organogenesis. 2020;16(2):61-72. https://doi. org $/ 10.1080 / 15476278.2020 .1742534$

130. Harper S, Hoff M, Skepper J, Davies S, Huguet E. Portal venous repopulation of decellularised rat liver scaffolds with syngeneic bone marrow stem cells. J Tissue Eng Regen Med. 2020;14(10): 1502-12. https://doi.org/10.1002/term.3117.

131. Hassanein W, et al. Recellularization via the bile duct supports functional allogenic and xenogenic cell growth on a decellularized rat liver scaffold. Organogenesis. 2017;13(1):16-27. https://doi. org/10.1080/15476278.2016.1276146.

132. Minami T, et al. Novel hybrid three-dimensional artificial liver using human induced pluripotent stem cells and a rat decellularized liver scaffold. Regen Ther. 2019;10:127-33. https://doi.org/10.1016/j.reth.2019.03.002.

133. Navarro-Tableros V, Herrera Sanchez MB, Figliolini F, Romagnoli R, Tetta C, Camussi G. Recellularization of rat liver scaffolds by human liver stem cells. Tissue Eng Part A. 2015;21(11-12):1929-39. https://doi.org/10.1089/ten.TEA. 2014.0573.

134. Zhou P, et al. Decellularization and recellularization of rat livers with hepatocytes and endothelial progenitor cells. Artif.Organs. 2016;40(3):E25-38. https://doi.org/10.1111/aor.12645.

135. Navarro-Alvarez $\mathrm{N}$, et al. Intramuscular transplantation of engineered hepatic tissue constructs corrects acute and chronic liver failure in mice. J Hepatol. 2010;52(2):211-9. https://doi. org/10.1016/j.jhep.2009.11.019.

Publisher's Note Springer Nature remains neutral with regard to jurisdictional claims in published maps and institutional affiliations. 